\title{
Политика в Церкви: воздействуют ли священники на электоральные предпочтения православных верующих?
}

\author{
М.И. БОГАЧЁВ*, К.В. СОРВИН**
}

\begin{abstract}
*Максим Игоревич Богачёв - кандидат социологических наук, преподаватель, Национальный исследовательский университет «Высшая школа экономики». Адрес: 101000, Москва, Мясницкая ул., д. 20. E-mail: mbogachev@hse.ru

**Кирилл Валентинович Сорвин - кандидат философских наук, доцент, заместитель декана факультета социальных наук, Национальный исследовательский университет «Высшая школа экономики». Адрес: 101000, Москва, Кривоколенный пер., д. 3. E-mail: ksorvin@hse.ru
\end{abstract}

Цитирование: Богачев М.И., Сорвин К.В. (2019) Политика в Церкви: воздействуют ли священники на электоральные предпочтения православных верующих? // Мир России. T. 28. № 4. C. 68-91. DOI: 10.17323/1811-038X-2019-28-4-68-91

Статья посвящена исследованию влияния православного духовенства и членов религиозных общин на электоральный выбор верующих. Эмпирически исследование опирается на соичологический опрос, проведенный в 2014-2015 годах через сочиальную сеть «ВКонтакте» среди людей, идентифищирующих себя как православных верующих $(N=2735)$. На материалах опроса проверялись гипотезы о распространенности, направленности и эффективности агитационного воздействия клира. Исследование показало, что 18,4\% респондентов стали свидетелями того, как православные священники затрагивали политические вопросы во время богослужений, 14,5\% респондентов сообщили, что при принятии избирательных решений в той или иной степени полагались на мнение священников. при этом частота посещения служб положительно коррелирует с частотой таких сообщений. В то же время 6,6\% респондентов не получали от духовенства никаких рекомендаций о голосовании, однако при формировании электоральных предпочтений они полагались на мнение общинников. Полученные результаты позволяют сделать вывод об ощутимом $и$ нетривиальном влиянии религии на электоральнье предпочтения верующих в современной России. Как минимум 21,1\% респондентов могут быть идентифицированы как подвергаюшиеся прямому политическому влиянию священников и членов православной общины.

Ключевые слова: социология религии, политология религии, политика и религия, выборы, православие, агитация, «Единая Россия» 


\section{Последствия сближения религиозных и политических категорий}

На протяжении последних десятилетий машина государственной и церковной пропаганды активно работает над формированием в массовом сознании граждан комплекса представлений об «идеальном россиянине». Создаваемый образ, помимо гражданского (родиться и прожить всю жизнь в России, иметь российское гражданство, уважать существующий политический срой) и культурного (говорить на русском языке, чувствовать себя россиянином) компонентов, включает в себя и религиозный элемент (быть православным ${ }^{1}$ ). Результатом совмещения этих компонентов в рамках идентификационного конструкта становится фактическое отождествление религиозной идентификации с этнической и гражданской (политической). Иными словами, религиозная принадлежность становится «субститутом гражданства» [Зоркая 2013]. Процесс сближения религиозных и политических категорий происходит не только на федеральном, но и на региональном уровне. Особенно ярко обозначенная тенденция проявляется в национальных республиках РФ, где значительная часть титульного этноса не исповедует христианство, и для населения этих регионов религия становится одним из важных элементов нациестроительства - символом национального своеобразия.

В качестве иллюстрации одного из симптомов сближения религиозных и политических категорий, происходящего в массовом сознании россиян, можно привести реакцию общества на акцию панк-рок группы Pussy Riot, прошедшую в 2012 г. в Храме Христа Спасителя. Провокационное выступление группы подобно лакмусовой бумаге проявило наличие в обществе полярных мнений по затронутой акционистами проблеме. При этом линия размежевания прошла сразу по двум наложившимся друг на друга вопросам - отношению к православной церкви и отношению к власти.

Политизация религии имела для российской общественно-политической жизни неоднозначные результаты. Одним из следствий, отразившихся в религиозной сфере, является принятие религиозными объединениями на вооружение средств политического воздействия, которые стали применяться для устранения конкурентов на религиозном рынке. Религиозные организации начали чаще использовать политический ресурс для лоббизма и продвижения собственных интересов в государственных органах (преподавание ОРКСЭ в школе, теология как научная специальность, институт военных капелланов и тюремного духовенства и другое) и для борьбы с оппонентами («закон о защите чувств верующих», «антимиссионерский» пакет поправок Яровой-Озерова, ликвидация «Саентологической церкви Москвы», признание «Свидетелей Иеговы» экстремистской организацией).

Данный процесс нашел отражение и в политической плоскости. В настоящее время партии, кандидаты и действующие должностные лица, стремясь получить поддержку религиозного электората, обращаются к религиозным сюжетам, апеллируют к религиозной идентичности избирателей и демонстрируют свою лояльность определенным религиозным группам и организациям. Обыденным явлением стало присутствие первых лиц государства и глав регионов, в большинстве

\footnotetext{
69\% россиян, опрошенных в 2012 г. Левада-Центром, выразили согласие с утверждением, что быть православным в той или иной мере важно «для того, чтобы считаться истинным россиянином» [Общественное мнение 2012, с. 17].
} 
своем представляющих партию «Единая Россия», на праздничных богослужениях (как правило, на рождественских и пасхальных). При этом руководство «Единой России» публично заявляет о своей опоре на Церковь и традиционные ценности [Мальцев 2012], заключает соглашение с РПЦ о сотрудничестве [«Единая Россия» и РПЦ 2010] и совершает паломничества к православным святыням [Руководство «Единой России» 2018]. Лидер КПРФ также заявляет о наличии у коммунистов и православных общих ценностей и общих врагов [Коммунизм и православие 2016], называет Христа «первым коммунистом в новом летоисчислении» [Зюганов считает Христа «первым коммунистом в новом летоисчислении» 2016] и говорит о совпадении содержания Нагорной проповеди и Кодекса строителей коммунизма [Зюганов: кодекс строителя 2012; Соборное согласие 2016; В КПРФ не поняли 2017]. Не забывают упомянуть о своей православной принадлежности и представители ЛДПР [Особое мнение с В. Жириновским 2016], трансляция крещенских купаний которых на ТВ стала уже традицией; не отстают от них и члены партии «Справедливая Россия» [Сергей Миронов посетил Храм 2011]². Однако эффективны ли подобные методы воздействия на избирателей для партий и кандидатов? Влияет ли публичная аффилиация политической силы с той или иной религией на ее электоральные результаты? Иными словами, оказывает ли религия ощутимое воздействие на электоральный процесс?

На Западе связь религиозных характеристик и политического поведения выявлена уже давно [Knutsen 2004; Van der Brug, Hobolt de Vreese 2009; McTague, Layman 2009]. При этом немаловажную роль в формировании политических взглядов западных верующих играет духовенство (и у католиков, и у различных протестантских деноминаций и церквей) [Wald, Calhoun-Brown 2014; Calfano, Oldmixon 2015]. Священники занимают стратегическое положение между политическими силами и религиозным электоратом. Клирики одновременно обладают доступом и к инфраструктуре (религиозным зданиям, приходским газетам и сайтам), и к людям. У церковных властей существует множество возможностей для того, чтобы транслировать верующим определенный политический посыл через такие каналы прямого влияния, как проповеди, пастырские послания, курсы катехизации, публикации на информационных стендах и в церковных СМИ [Wald, Owen, Hill 1988]. Тем не менее до конца не определено, применимы ли выводы, полученные на материалах западных стран, к российским реалиям, несущим на себе отпечаток не только посткоммунистического наследия, но и преобладания в религиозном пространстве восточной ветви христианства (редко попадающей под объектив зарубежных исследователей). Иными словами, однозначного ответа на вопрос, влияет ли религия на электоральные предпочтения верующих в России, и какую роль в этом процессе играют священники, до сих пор нет ни у академического, ни у экспертного сообщества [Представители религиозных организаций и политологи 2003].

Существующие исследования или имеют ограниченный эвристический потенциал, или приходят к неоднозначным, а подчас и противоположным выводам.

\footnotetext{
2 Необходимо отметить, что борьба между политическими силами разворачивается не только за голоса верующих, но и неверующих россиян. Например, атеистов под свои знамена призывали «Гражданская платформа» М.Д. Прохорова и партия-спойлер КПРФ - «Коммунисты России», которая даже учредила общественную организацию под названием «Атеисты России». Также антиклерикальная риторика прослеживалась в речах и действиях другого левого движения - Российской рабочей коммунистической партии (РКРП). Для обзора более раннего периода см.: [Рябых 2004].
} 
Так, в одних работах фиксируется, что различия между неверующими и верующими, а также верующими, с разной интенсивностью совершающими религиозные практики, «занимают свою мировоззренческую, социокультурную нишу и не переходят в политическую плоскость» [Локосов 2006], в то время как в других констатируется наличие у указанных групп значимых расхождений по вопросам о доверии политическим институтам [Локосов, Синелина 2004; Локосов, Синелина 2008] и отмечается, что в России посещение религиозных служб увеличивает вероятность приобщения человека к различным формам политического участия [Кулькова (2) 2015]. Некоторые обществоведы утверждают, что между типологическими группами не существует значимых различий по политическим вопросам (о наиболее предпочтительной форме правления, об отношении к демократии и либерализму), но имеются расхождения по вопросам культурного характера (относительно цензуры и равноправия различных религиозных организаций) [Ситников 2012]. При этом другие авторы настаивают, что в России между нерелигиозными людьми и теми, кто регулярно посещает религиозные мероприятия, нет значимой разницы даже по такому животрепещущему для верующих вопросу, как отношение к сексуальным меньшинствам [Кулькова (1) 2015], т.е. можно утверждать, что проблемное поле соотношения политики и религии изучено явно недостаточно. В частности, открытым остается вопрос о роли священников и членов приходских общин в процессе формирования электоральных предпочтений верующих. Ответу на него и посвящено это исследование.

Структурно статья состоит из двух смысловых блоков - теоретического и практического. В первом разделе освещается феномен политической агитации со стороны клира: уточняется содержание понятия «политическая агитация», раскрывается отношение церковного руководства к данному явлению, указываются формы, в которых священники могут проводить то, в чем можно усмотреть политическую агитацию. Второй раздел посвящен изучению распространенности осуществляемой духовенством агитации в современной России, в нем формулируются гипотезы исследования, описывается массив данных и приводятся результаты его анализа.

\section{Агитация клира: легальность, формы, распространенность}

Российское законодательство в понятие политической агитации включает широкий перечень действий. В частности, статья 48 N67-Ф3 «Об основных гарантиях избирательных прав и права на участие в референдуме граждан Российской Федерации» в качестве предвыборной агитации признает:

«а) призывы голосовать за кандидата, кандидатов, список, списки кандидатов либо против него (них);

б) выражение предпочтения какому-либо кандидату, избирательному объединению, в частности указание на то, за какого кандидата, за какой список кандидатов, за какое избирательное объединение будет голосовать избиратель;

в) описание возможных последствий в случае, если тот или иной кандидат будет избран или не будет избран, тот или иной список кандидатов будет допущен или не будет допущен к распределению депутатских мандатов; 
г) распространение информации, в которой явно преобладают сведения о каком-либо кандидате (каких-либо кандидатах), избирательном объединении в сочетании с позитивными либо негативными комментариями;

д) распространение информации о деятельности кандидата, не связанной с его профессиональной деятельностью или исполнением им своих служебных (должностных) обязанностей;

е) деятельность, способствующая созданию положительного или отрицательного отношения избирателей к кандидату, избирательному объединению, выдвинувшему кандидата, список кандидатов» [Федеральный закон «Об основных гарантиях избирательных прав и права на участие в референдуме граждан Российской Федерации» 2002].

Следует уточнить, что в настоящей статье авторы, обобщая данные признаки, в качестве политической агитации будут признавать любые действия, совершенные с целью побуждения избирателей голосовать или, напротив, не голосовать за какого-либо кандидата или список кандидатов.

Говоря о формально-правовой стороне вопроса, нужно заметить, что в России федеральное законодательство запрещает религиозным организациям, членам и участникам религиозных объединений проводить предвыборную агитацию, a также выпускать и распространять любые агитационные материалы [Федеральный закон «Об основных гарантиях избирательных прав и права на участие в референдуме граждан Российской Федерации» 2002]. Однако если религиозным организациям политическая агитация не разрешена в любом виде, то для членов и участников религиозных объединений недопустимо проводить предвыборную агитацию только при совершении обрядов и церемоний, т.е. в момент исполнения ими своих должностных или служебных обязанностей. Оставленную светским законодательством лакуну заполняют официальные документы РПЦ, которые запрещают своим священнослужителям участие в политической агитации. В частности, об этом гласит постановление Архиерейского собора «О взаимоотношениях с государством и светским обществом», предписывающее «считать недопустимым участие архиереев и священнослужителей в какой-либо предвыборной агитации» [Основы социальной концепции РПЦ 2000]. Данная точка зрения отражена и в «Основах социальной концепции РПЦ», где прописывается запрет на участие священнослужителей в деятельности политических организаций, политической агитации и поддержку участвующих в выборах организаций и кандидатов [Основы социальной концепции РПЦ 2000]. К содержанию именно этих церковных документов, как правило, апеллируют официальные представители Церкви, когда в публичном пространстве затрагиваются вопросы воздействия РПЦ на политическую жизнь российского общества. На протяжении двух последних десятилетий о церковном нейтралитете говорили и патриарх Алексий II (Ридигер) [Церковь будет соблюдать нейтралитет на выборах 2003], и патриарх Кирилл (Гундяев) [Церковь не будет поддерживать «Единую Россию» 2011; Патриарх Кирилл призвал 2017], и глава синодального Отдела по взаимоотношениям Церкви и общества протоиерей Всеволод Чаплин [Чаплин напомнил 2011], и глава синодального Отдела внешних церковных связей митрополит Волоколамский Иларион [Русская православная церковь не участвует в предвыборной агитации 2018].

Вместе с тем православные иерархи признают, что священники могут влиять на политический выбор верующих. Так, патриарх Кирилл (Гундяев) в период, когда 
он занимал кафедру митрополита и председательствовал в Отделе внешних церковных связей (ОВЦС), заявлял, что «потенциально Церковь может влиять на результаты голосования - ведь огромное количество верующих обращается за духовным советом к батюшкам в период выборов» [Церковь - над предвыборной «схваткой» 2003]. При этом положения тех же церковных документов, к которым апеллируют клирики, говоря о необходимости невмешательства Церкви в политический процесс, дозволяют священнослужителям обходить запреты и выражать как общецерковное, так и собственное мнение по вопросам политического характера.

«Неучастие церковной Полноты в политической борьбе, в деятельности политических партий и в предвыборных процессах не означает ее отказа от публичного выражения позиции (выделено авторами) по общественно значимым вопросам, от представления этой позиции перед лицом органов власти любой страны на любом уровне» [Основы социальной концепции РПЦ 2000].

«Отказ Церкви от участия в политической борьбе не следует воспринимать как ее самоустранение от происходящего в стране и мире. Церковь оставляет за собой право давать нравственную оценку (выделено авторами) политическим программам и заявлениям. $<\ldots>$ Это свое право Церковь сохраняет и во время избирательных кампаний.

В контексте избирательной кампании уместно призывать граждан к осмысленному участию в голосовании (выделено авторами), а политиков - к проведению честных выборов, к снижению накала политических страстей, к заботе о мире, солидарности и согласии в обществе» [Практика заявлений и действий 2011].

В то же время установление границы между политической агитацией и высказыванием позиции по общественно значимым вопросам, между предоставлением нравственной оценки политическим программам и призывам к осмысленному участию в голосовании остается за представителями Церкви, что дает клиру существенное пространство для маневра. Оценочные суждения священника о той или иной политической силе, равно как и заявление о своем личном мнении о партии или кандидате, также влияют на электоральные предпочтения верующих, однако формально (с точки зрения церковного права) не являются политической агитацией. Данная норма позволяет клиру, действуя в рамках церковного правового поля, отказывать одним политическим силам, ищущим ее поддержки, и одновременно содействовать другим политическим игрокам.

Наличие возможности при необходимости обойти запрет на вовлечение духовенства в политику открыто признают и сами священнослужители.

«Если священник не имеет права напрямую участвовать в политической жизни, то своими проповедями, своим словом, своей нравственной позицией, выражаемой так или иначе, священник может влиять на жизнь вообще, в том числе и на политическую» [Священник Александр Шумский 2011].

Таким образом, официальная позиция РПЦ в отношении политической агитации священников является дуалистичной: с одной стороны, Церковь прописывает запрет на участие священства в политическом процессе, но, с другой, оставляет 
множество возможностей для проведения священниками действий, которые по существующему определению являются политической агитацией.

Политическая агитация, в том числе осуществляемая священнослужителями, может быть классифицирована (1) в зависимости от количества граждан, подпадающих под воздействие, как индивидуальная и массовая (агитация в личной беседе или в процессе коллективной проповеди); (2) в зависимости от степени очевидности призыва - как прямая и косвенная. К прямой агитации относится информация, которая в явной и четкой форме побуждает человека к избранию или действиям обратного характера в отношении определенной партии, кандидата. Примером прямой агитации может служить видеоролик, в котором зафиксировано, как епископ Домодедовский Евтихий (Курочкин) в ходе службы призывает верующих проголосовать на выборах Президента РФ за кандидатуру В.В. Путина.

«Я, как и многие из вас, нахожу много неправильного у нашего правительства. Вот и не советую никогда ввязываться в какие-то политические, партийные дела, но на предстоящие выборы я прошу идти и голосовать за Путина! Почему? Потому что это самая большая гарантия, что покой будет. При любой перемене могут быть даже неожиданные нами волнения, смута, неразбериха» [Епископ Евтихий агитирует за Путина 2012].

Косвенной агитацией являются сведения, которые побуждают человека к голосованию за политическую силу или воздержанию от этого в неявном, завуалированном виде, когда информация о том или ином кандидате преподносится в выгодном или же, наоборот, порочащем ее свете, что демонстрируется в видеоролике, где протоиерей Владимир Головин отвечает на вопросы верующих:

«- Будете ли Вы голосовать на выборах президента? Если да, то за кого?

- <..> если б пошел голосовать, я бы голосовал не за имя, а за того, кто уже есть, чтоб поменьше было проходящих проходимцев. За того, который есть, и неважно, какая его фамилия на сегодняшний день» [Протоиерей Владимир Головин отвечает на вопросы 2018].

Раскрыть механизм косвенного воздействия священника на политический выбор верующих помогают слова игумена Нектария (Морозова).

«Когда люди спрашивают нас, за кого им голосовать, то ответ священника на этот вопрос не будет корректен, если он скажет: “Голосуйте за коммунистов, голосуйте за единороссов”. < . .> Мы должны давать людям верные критерии различения добра и зла (выделено авторами), а решение россияне пусть делают сами. Нельзя позволять втягивать Церковь в водоворот страстей, политической борьбы и мешать ей выполнять свое главное предназначение» [Выбор все-таки за нами 2011]. 
Предоставление критериев для различения добра и зла, очевидно, не является агитацией, но вопрос заключается в том, что будет пониматься под такими критериями, насколько их формулировка действительно сохранит свободу выбора, а не создаст всего лишь его видимость. Предложенные протоиреем Андреем Ткачевым мерила для оценивания политических деятелей значительно ограничивают доступный избирателю перечень политических альтернатив (мужчина, а не женщина; созревший, а не молодой).

«Какие, кроме воздержания и чистоты, требования можно и нужно ожидать от властей? Что говорит Писание? Говорит, например, что правитель не должен быть очень молод. Это должен быть созревший и успевший закалиться муж. Причем лучше муж, чем жена, поскольку не для начальства сотворил Господь Бог женщину. <..> Править должны мужчины. И не малолетки, окруженные регентами и временщиками, а созревшие умом и силами мужи. Это вполне здравое и естественное требование» [Ткачев 2017].

Иными словами, священнику для того, чтобы повлиять на предпочтения верующих необязательно прямым текстом говорить о приоритетности той или иной партии, кандидата, достаточно указать пастве на критерии для сравнения политических сил, используя которые верующие самостоятельно придут к нужному для пастыря мнению, воспринимая при этом данное решение не как навязанное, а как свое собственное.

Точных данных о распространенности действий, подпадающих под определение политической агитации, проводимой священнослужителями традиционных для России религий, на данный момент не существует ${ }^{3}$ Однако результаты исследования А.Ю. Кульковой, проводившей в 2014 г. телефонные интервью со священниками 20 московских православных храмов, демонстрируют, что подобная агитация в приходах РПЦ является частой практикой: «<...> представители большинства исследуемых общин, так или иначе, сказали, что в их общинах в предвыборный период возможна агитация за какую-то политическую силу, а также призывы “пойти и проголосовать”» [Кулькова (2) 2015, с. 35].

При отсутствии адекватных представлений о масштабах агитации в российских православных церквях небезынтересными становятся результаты иностранных исследований, посвященных изучению распространенности случаев осуществления священниками политической агитации. Данные опроса, проведенного в 2016 г. в Грузии, свидетельствуют, что $35 \%$ респондентов при принятии решения о том, за кого голосовать, полагаются на мнение священника и единоверцев [На политические взгляды 35\% опрошенных влияет священник 2016]. В свою очередь исследование, проведенное в 2016 г. в США, зафиксировало, что среди верующих, посещающих службы хотя бы один раз в месяц, 64\% были очевидцами того, как священник прямо говорил что-либо в поддержку или против кандидата на пост президента США [Many Americans Hear Politics From the Pulpit 2016]. Конечно, данные, полученные в странах с другими политическими и религиозными традициями, не могут напрямую

3 Вместе с тем есть основания предполагать, что данная проблема актуальна и для духовенства, и для мирян РПЦ [Открытое письмо православных верующих по поводу участия Церкви в предвыборной агитации 2011]. 
переноситься в российский контекст, однако они могут служить дополнительным источником для выдвижения исследовательских гипотез.

Таким образом, есть основания предполагать, что священники РПЦ могут являться инструментом для политической агитации среди такой категории российского электората, как православные верующие.

\section{Гипотезы, массив и анализ данных}

Опираясь на вышеприведенные материалы, авторы сформулировали несколько подлежащих верификации гипотез.

Первая гипотеза имеет своей целью фиксацию распространенности случаев массовой политической агитации, осуществляемой священниками. Священнослужители, высказываясь по каким-либо политическим вопросам во время проповедей, могут явно или косвенно агитировать верующих поддержать ту или иную политическую силу. Следовательно, $\mathbf{H}_{1}$ подразумевает, что «чем чаще человек совершает коллективные религиозные практики (например, посещает службы ${ }^{4}$ ), тем чаще он становится свидетелем политической агитации со стороны клира».

Вторая гипотеза ориентирована на определение эффективности проводимой священниками агитации и касается восприятия мирянами мнений клира. Предполагается, что верующие, регулярно посещающие службы, будут следовать политическим предписаниям и советам священства чаще, чем верующие, присутствующие на службах от случая к случаю. Таким образом, $\mathbf{H}_{2}$ состоит в том, что «чем чаще человек посещает службы, тем чаще он прислушивается к мнению священства по вопросам политического характера».

Третья гипотеза касается восприятия мирянами мнений своих единоверцев, состоящих с ними в одних и тех же религиозных общинах. Регулярное совершение религиозных практик способствует формированию вокруг индивида соответствующего социального окружения, которое неизбежно влияет на него и становится референтной группой. Соответственно, $\mathbf{H}_{3}$ звучит следующим образом: «чем чаще человек посещает службы, тем чаще он прислушивается к мнению общинников по вопросам политического характера».

Для проверки предположения о роли священников и общинников в формировании политических предпочтений верующих авторами исследования был проведен социологический опрос «Социально-политические предпочтения российского общества», в ходе которого верующим задавались вопросы об их религиозных практиках и политических предпочтениях, частоте высказывания со стороны священников рекомендаций политического характера, следовании озвучиваемым священниками советам и т.п. Анкетирование проводилось среди пользователей социальной сети «ВКонтакте», числящихся в различных (преимущественно религиозно ориентированных) сообществах, по нерепрезентативной выборке без

\footnotetext{
4 В качестве индикатора религиозности индивидов в данной работе используется такая характеристика религиозного поведения, как частота посещения религиозных служб. На сегодняшний день этот показатель является одним из наиболее употребляемых и достоверных инструментов для определения вовлеченности верующего в религиозную среду и его приверженности религиозным нормам.
} 
использования квот в декабре 2014 - январе 2015 гг. Выборка исследования составила 6259 чел., из которых 2735 чел. идентифицировали себя как православных верующих. Статистическая погрешность не превышает отметки в 1,6\% ${ }^{5}$.

Среди попавших в выборочную совокупность православных россиян 58,2\% составили женщины, 41,8\% - мужчины. По возрастным группам верующие распределились следующим образом: 6\% - в возрасте от 10 до 17 лет ${ }^{6}, 31,1 \%$ - от 18 до 24 лет, 31,3\% - от 25 до 34 лет, 15,5\% - от 35 до 44 лет, 13,3\% - от 45 до 59 лет, $2,8 \%$ старше 60 лет, т.е. 62,4\% находились в возрастном диапазоне от 18 до 34 лет. Необходимо отметить, что экстраполяция результатов данного исследования на все население РФ некорректна, так как генеральная совокупность опроса представлена только пользователями социальной сети «ВКонтакте». Тем не менее результаты исследования, во-первых, позволяют сформировать первичное представление о распространенности и направленности феномена осуществляемой священством политической агитации, во-вторых, при некоторых оговорках могут быть перенесены на пользователей крупнейшей социальной сети России, ежемесячная аудитория которой на 2015 г. составляла 53,6 млн чел. [Социальные сети в России 2015].

Попавшие в выборочную совокупность верующие были подразделены на пять групп в зависимости от частоты посещениями ими религиозных служб․ Категория респондентов, позиционирующих себя как православных верующих, но никогда не посещавшие религиозные службы, получила наименование «невоцерковленной» (2,4\% от общей выборки). Верующие, присутствовавшие на службе раз в год и реже, были маркированы как маловоиерковленные (16,7\%). Православные, бывающие на службах несколько раз в год, были обозначены как средневоцеековленные (24,7\%). Верующие, посещающие религиозные службы с частотой от одного до трех раз в месяц, были определены как воцерковленные $(25,4 \%)$. Респонденты, присутствовавшие на службах раз в неделю и чаще (т.е. характеризующиеся наивысшими показателями религиозной активности на используемой в исследовании шкале), получили название сильновоцерковленные $(30,8 \%)^{8}$.

Для проверки гипотезы о распространенности проводимой духовенством политической агитации респондентам предлагался вопрос «Были ли Вы очевидцем того, как священник во время проповеди выражает мнение по тому или иному политическому вопросу?» Вопросу заведомо была дана обтекаемая формулировка, не включающая слово «агитация», поскольку прямой вопрос о проводимой священнослужителем агитации мог вызвать у верующих (особенно у сильновоцер-

\footnotetext{
5 Статистическая погрешность рассчитана по стандартной формуле при помощи опции, предоставленной компанией «Маркетинговое агентство MA FDFgroup».

6 Данная группа была исключена из дальнейшего анализа.

7 В данной статье используется минималистская концепция воцерковленности, операционализирующая воцерковление, т.е. процесс усвоения установленного в Церкви образа жизни и образа мыслей, только через частоту посещения религиозных служб.

8 В модели В.Ф. Чесноковой, создателя одного из первых индексов воцерковленности, для попадания в категорию воцерковленных верующих («церковного народа») было достаточно посещения служб с периодичностью раз в месяц [Чеснокова 2005]. Однако в настоящем исследовании шкала частоты посещения религиозных служб была увеличена до отметки раз в неделю и чаще (каждую неделю); в свою очередь группа, с указанной регулярностью присутствовавшая на службах, составила наивысшую по степени воцерковленности категорию. Для обозначения новой группы, характеризующейся большей степенью религиозной активности, чем воцерковленные в модели В.Ф. Чесноковой, было решено использовать наименование сильновоцерковленные.
} 
ковленных) отторжение. Кроме того, некоторая неопределенность формулировки позволяла вместить в вопрос широкий диапазон тематик, которые могли быть маркированы верующими как политические. Результаты вышеприведенного анализа институциональных рамок, регулирующих проводимую духовенством политическую агитацию, говорят в пользу того, что существующие «правила игры» стимулируют священников в большей степени задействовать формы косвенной, а не прямой агитации, т.е. приводить аргументы из разных сфер, на первый взгляд, не связанных с политикой. Поэтому при изучении феномена осуществляемой духовенством политической агитации было очень важно не ограничивать перечень тематик, которые могли бы быть отмечены как политические.

\section{Были ли Вы очевидцем того, как священник во время проповеди выражает мнение по тому или иному политическому вопросу?}

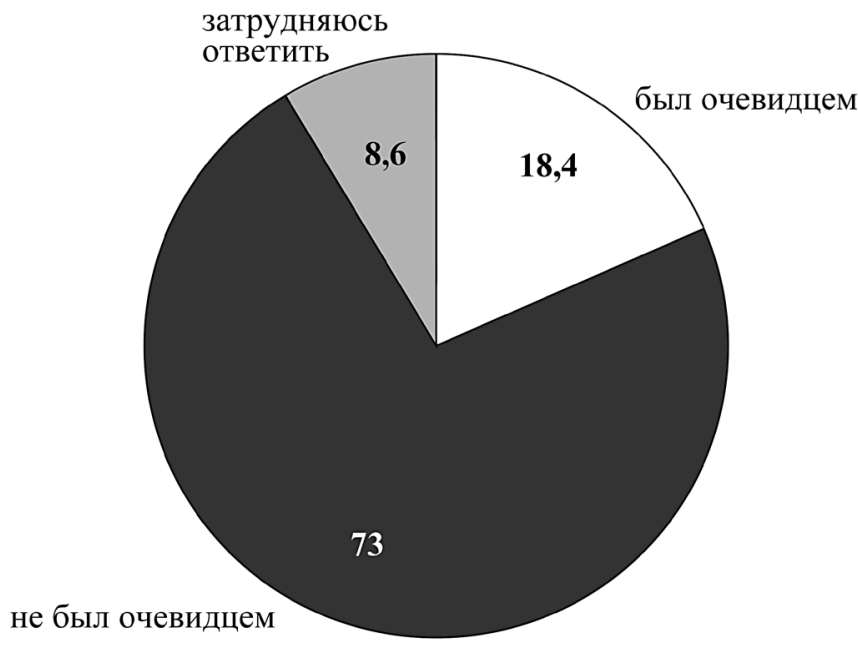

Рисунок 1. Доля православных верующих, являющихся очевидцами проводимой духовенством политической агитации, \%

В ходе анализа ответов православных верующих было выявлено, что очевидцами того, как священник во время службы проводит политическую агитацию (выражает мнение по тому или иному политическому вопросу), оказались 18,4\% опрошенных, 73\% респондентов с подобной ситуаций не сталкивались, а 8,6\% затруднились с ответом (рисунок 1). При этом увеличение степени воцерковленности (т.е. учащение посещения религиозных служб от категории «раз в год и реже» до категории «каждую неделю») сопровождалось возрастанием доли верующих, запомнивших политическую агитацию священства - с 8,8 до 26,8\% ${ }^{9}$ (рисунок 2).

\footnotetext{
9 Здесь и далее значимость различий долей между группами оценивались с помощью построения доверительных интервалов (на 95\% уровне доверия) и изучения их пересечения/непересечения.
} 


\section{Были ли Вы очевидцем того, как священник во время проповеди выражает мнение по тому или иному политическому вопросу?}

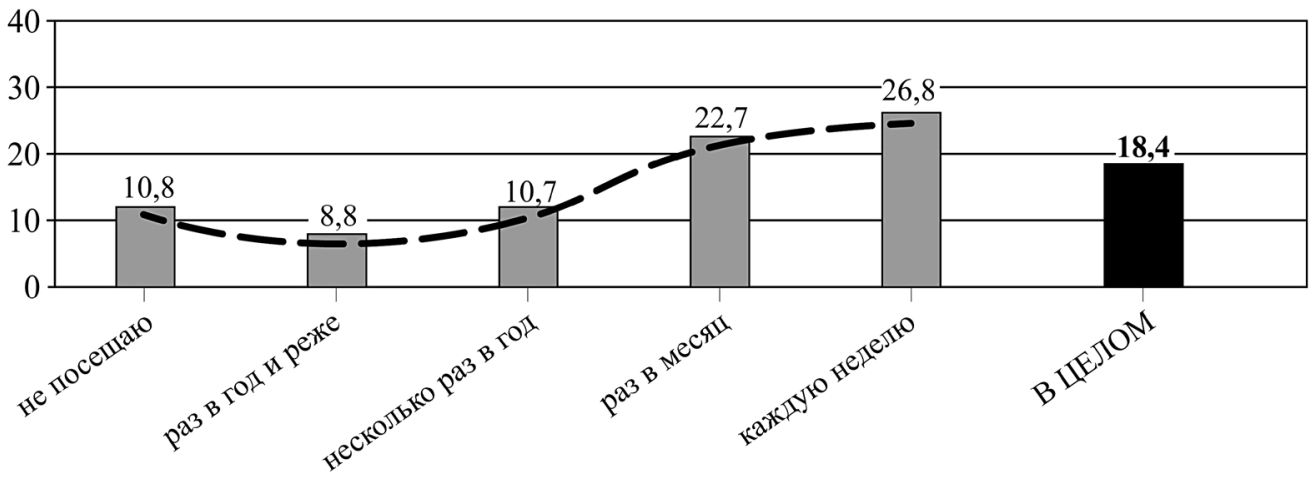

Рисунок 2. Соотношение степени воцерковленности и доли верующих, зафиксировавших проводимую священником агитацию ${ }^{10}, \%$

Вышеприведенные данные подтверждают гипотезу $\mathbf{H}_{1}$ : «чем чаще человек посещает религиозные службы, тем чаще он становится очевидцем политической агитации, проводимой представителями духовенства». Однако следовало определить, какая доля верующих следует озвучиваемым священниками предписаниям и рекомендациям. Поэтому в ходе исследования респондентам задавался вопрос «Руководствовались ли Вы советами/намеками/мнением священника при принятии решения о голосовании за ту или иную партию/кандидата?» Шкала ответов на него, кроме полярных вариантов «руководствовался/не руководствовался» и традиционного «затрудняюсь с ответом», включала в себя буллит «прислушивался к мнению священника, но окончательное решение принимал самостоятельно» ${ }^{11}$. Анализ распределения ответов респондентов на данный вопрос свидетельствует, что 79,3\% православных верующих при принятии решения о том, за кого

\footnotetext{
10 В группе респондентов, заявивших, что они не посещают религиозные службы, 10,8\% ответили, что были очевидцами проводимой духовенством агитации. Данная ситуация может быть объяснена тем, что сегодня многие верующие контактируют с церковным кругом посредством радио, телевидения и интернета. Православные станции, каналы и блоги, генерирующие и транслирующие соответствующий контент, широко представлены среди современных СМИ. Кроме того, православные священники являются частыми спикерами в светских программах и изданиях. Поэтому неудивительно, что многие невоцерковленные, но воспринимающие и позиционирующие себя как православные верующие, получают информацию о церковной жизни и церковной позиции не непосредственно в стенах храма, а опосредовано через СМИ.

11 Включение данного варианта позволило, с одной стороны, в ходе опроса запечатлеть эффект от проводимой духовенством косвенной агитации, а с другой, учесть верующих, которым психологически некомфортно признавать, что в ряде случаев они оказываются ведомыми и полагаются на чужое мнение. Для многих представителей данной категории граждан ответ «прислушивался» является более предпочтительным, чем «руководствовался», так как присутствующий в нем оттенок самостоятельности позволяет верующим убеждать себя в самостоятельности принятого решения. В то же время в действительности их собственные умозаключения базируются на предоставленных священником понятиях и суждениях и выводятся в рамках заданного священнослужителем вектора. В связи с этим в ряде случаев ответы «руководствующихся» и «прислушивающихся» респондентов будут рассматриваться как сумма долей верующих, которые в той или иной степени полагаются на мнение священнослужителя.
} 
голосовать, мнением духовенства не руководствовались, 12,8\% прислушивались к рекомендации священника, $1,7 \%$ руководствовались полученным от священнослужителя советом, а 6,2\% респондентов затруднились с ответом (рисунок 3 ).

Как и предполагалось, увеличение воцерковленности оказалось сопряжено с увеличением доли православных, прислушивающихся к мнению клириков (с 3,1 до 20\%). Также можно утверждать, что среди воцерковленных и сильновоцерковленных православных верующих «руководствовавшихся» больше, чем среди мало- и средневоцерковленных (рисунок 4). Таким образом, подтверждается гипотеза $\mathbf{H}_{2}$ : «чем чаще человек посещает религиозные службы, тем чаще он прислушивается к мнению духовенства по вопросам политического характера».

Если сложить доли верующих, которые при принятии решения «руководствуются» и «прислушиваются» к мнению духовенства, то получится 14,5\%. Иными словами, каждый шестой опрошенный верующий признает, что в вопросах об электоральных предпочтениях в той или иной степени полагается на мнение пастыря $^{12}$. Следует подчеркнуть, что в выборке проведенного опроса доминировала молодежь, поэтому можно предположить, что среди представителей старших возрастных когорт, преобладающих в структуре общности российских православных, доля верующих, полагающихся на мнение пастыря, может оказаться еще больше. Таким образом, было выявлено, что среди попавших в выборочную совокупность православных 18,4\% были очевидцами того, как священнослужитель во время проповеди проводил массовую политическую агитацию паствы. В свою очередь 14,5\% респондентов сообщили, что полагались на мнение духовенства при принятии решения о том, за какую политическую силу им проголосовать.

Необходимо отметить, что вопрос «Были ли Вы очевидцем того, как священник во время проповеди выражает мнение по тому или иному политическому вопросу?» был ориентирован на выявление распространенности случаев массовой (публичной) агитации и не позволяет сделать выводы о распространенности случаев агитации, проводимой священниками в индивидуальном порядке. Между тем личные беседы на политические темы (даже если они инициированы самими прихожанами) также могут рассматриваться как агитация, если они содержат (1) призывы к голосованию за какого-либо кандидата/партию; (2) выражение предпочтения какому-либо кандидату/партии; (3) информацию, способствующую созданию положительного/отрицательного отношения к кандидату/партии. Сформировать некоторые представления о распространенности индивидуальной агитации верующих, осуществляемой духовенством, можно, если соотнести подмножества верующих, которые полагаются на мнение священника, и верующих, которые были очевидцами проводимой священником агитации. Анализ данных подмножеств позволяет выявить следующие распределения.

\footnotetext{
12 Примечательно, что схожий результат был зафиксирован и в другом исследовании. В рамках научного проекта «Традиционные религии в постсекулярном обществе: на примере социологического исследования приходов Екатеринбургской митрополии», проводимого под руководством Е.И. Гришаевой, в июне-сентябре 2015 г. в трех городах Свердловской области (Екатеринбурге, Нижнем Тагиле, Кировограде) были опрошены 1042 прихожанина православных храмов. В ходе опроса у респондентов, кроме прочего, спрашивали: «Насколько часто Вы советуетесь со священником по вопросам политической жизни, выборов, митингов?» 2,5\% опрошенных ответили, что советуются «достаточно часто», 3,2\% - «несколько раз», 9,5\% - «однажды», 84,8\% сообщили, что «не советуются». Таким образом, 15,2\% всех опрошенных хотя бы один раз советовались со священником по вопросам политической жизни, выборов, митингов.
} 
Руководствовались ли Вы советами священника при голосовании?

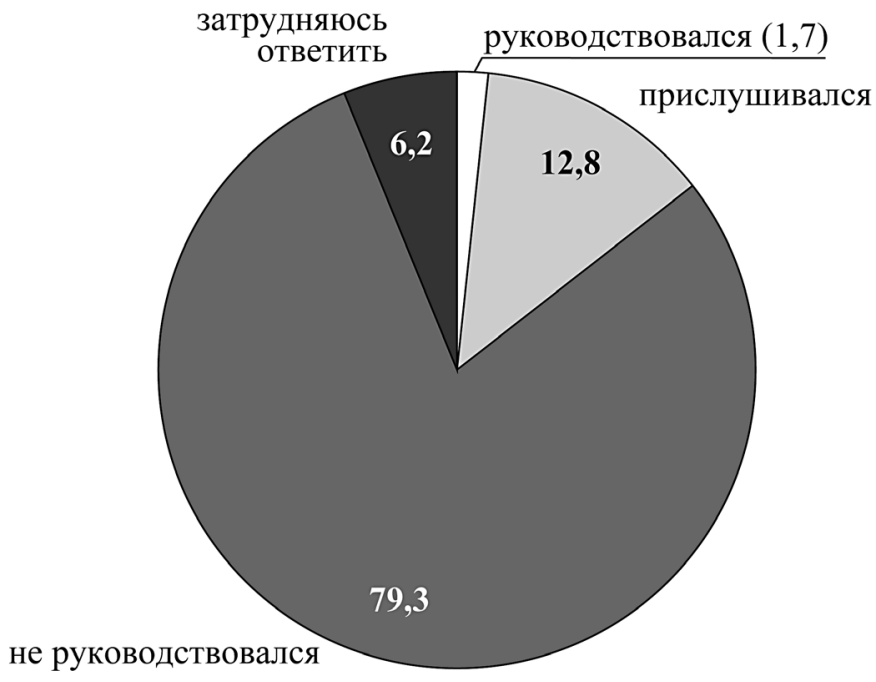

Рисунок 3. Доля православных верующих, которые при голосовании руководствуются мнением священнослужителя, \%

Руководствовались ли Вы советами священника при голосовании?

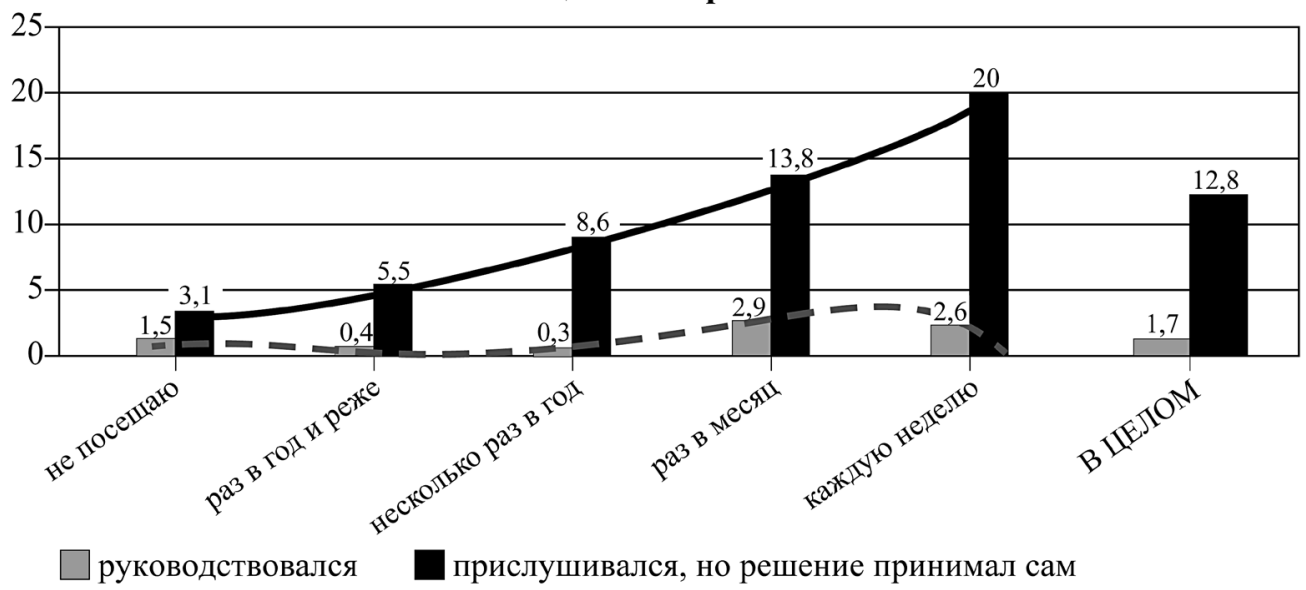

Рисунок 4. Соотношение степени воцерковленности и доли верующих, которые при голосовании прислушиваются к мнению священника или руководствуются им, \% 


\section{Приниматете ли Вы участие}

в жизни религиозной общины?

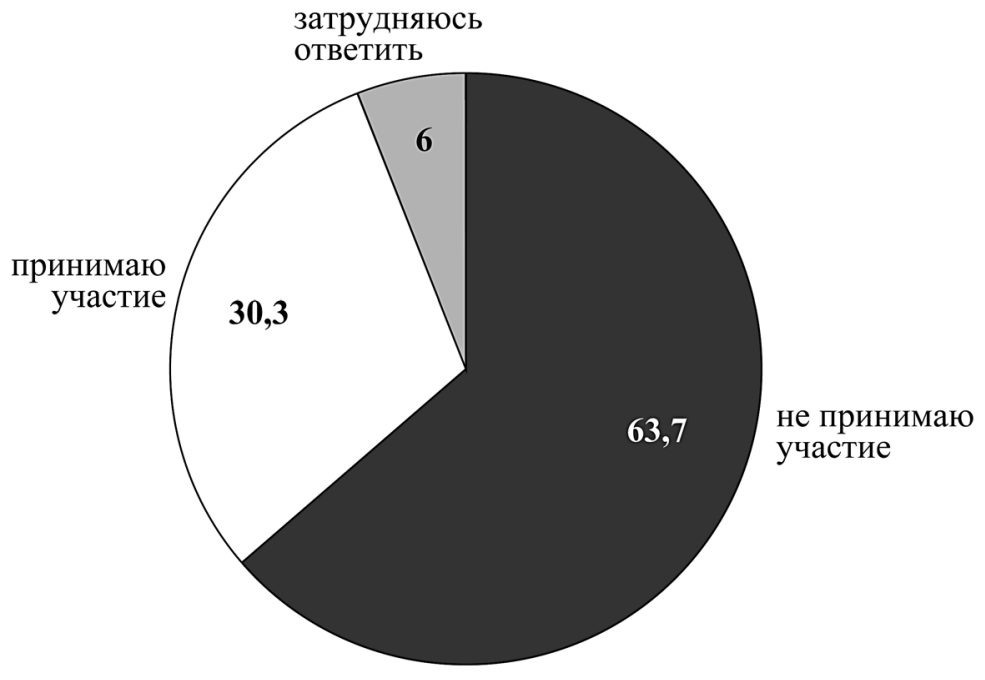

Рисунок 5. Доля православных, принимающих участие в жизни общины, \%

Принимаете ли Вы участие в деятельности какой-либо религиозной общины (не считая посещения служб)?

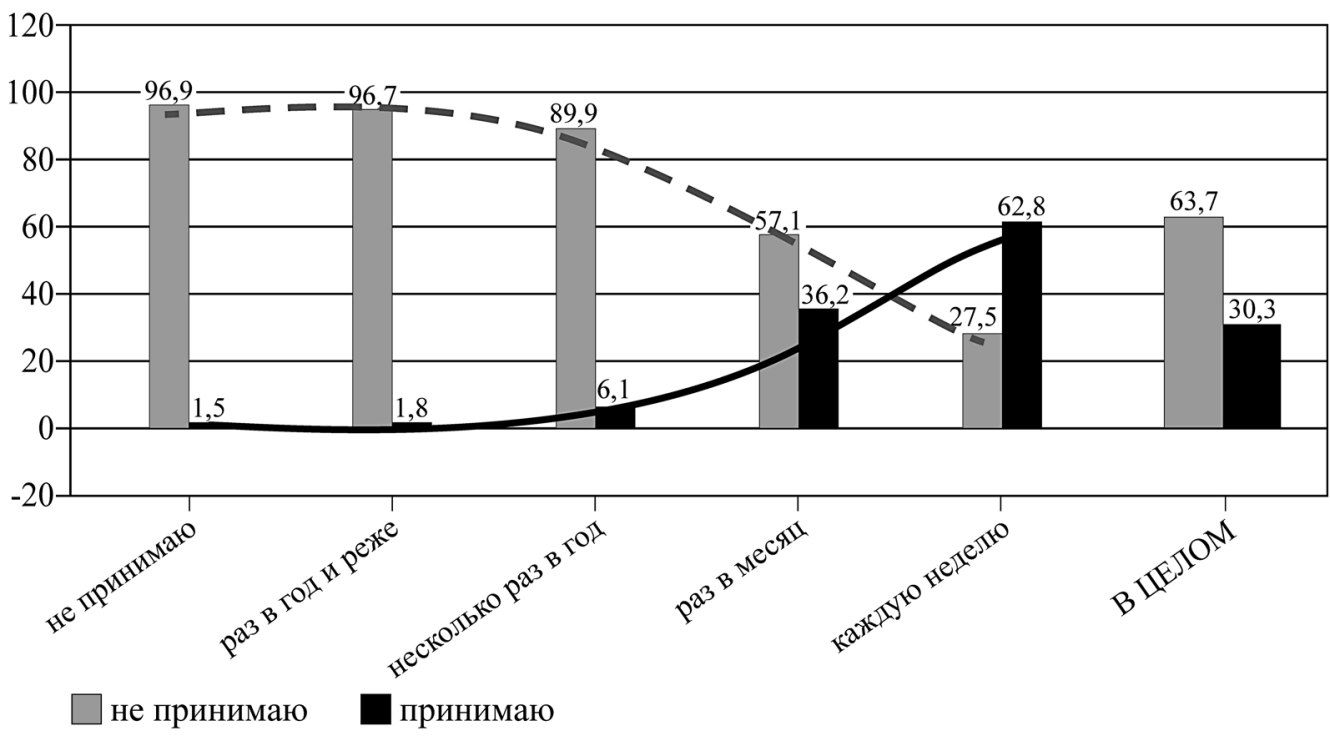

Рисунок 6. Соотношение воцерковленности и участия в делах общины, \% 
Среди верующих, полагающихся при голосовании на мнение духовенства, только 41\% были очевидцами проводимой священниками агитации. В свою очередь 49\% православных не слышали, чтобы пастыри во время службы (наблюдаемой ими при непосредственном нахождении в храме или же посредством просмотра трансляции в СМИ) говорили о политике и проводили массовую агитацию верующих. То есть половина православных верующих, следующих воле священника в избирательных вопросах, не сталкивалась с тем, чтобы священнослужитель говорил о политике во время службы. Предположительно указание на наиболее предпочтительную для голосования политическую силу для данной группы верующих было озвучено священником в личной беседе и являлось ответом на вопрос, заданный прихожанином по собственной инициативе после окончания богослужения.

Следующий вопрос - роль религиозных общин в процессе формирования политических предпочтений верующих. Согласно данным проведенного опроса, среди попавших в выборку православных верующих 30,3\% в той или иной степени вовлечены в жизнь религиозной общины, 63,7\% не принимают какого-либо участия в деятельности прихода, а 6\% затруднились с ответом (рисунок 5). Как и ожидалось, по мере учащения посещения служб доля верующих, вовлеченных в приходскую жизнь, увеличивается (с 1,5 до 62,8\%) (рисунок б).

Среди верующих, участвующих в приходской жизни (т.е. среди $30,3 \%$ от всех попавших в выборку православных), на вопрос «Руководствовались ли Вы мнением членов религиозной общины, в которой Вы состоите, при принятии решения о голосовании за ту или иную партию/кандидата?» положительно ответили только $2 \%$, отрицательно - 70,1\%, при этом 20,7\% православных сказали, что прислушивались, а 7,2\% затруднились с ответом (рисунок 7).

\section{Руководствовались ли Вы мнением членов религиозной общины при голосовании?}

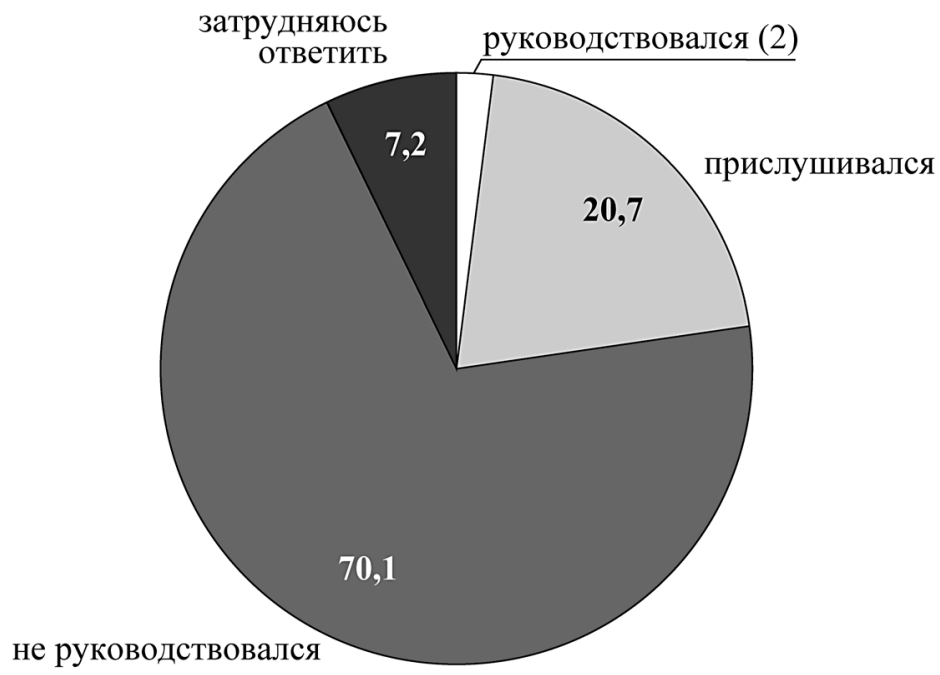

Рисунок 7. Доля респондентов, которые при голосовании полагаются на мнение общинников, среди православных верующих, принимающих участие в жизни общины, \% 
Таким образом, каждый пятый верующий $(22,7 \%)$, состоящий в религиозной общине, при принятии решения о голосовании в той или иной степени полагается на мнение окружающих его прихожан.

Неудивительно, что доля прихожан, которые при голосовании полагались на мнение своих товарищей по общине, увеличивается по мере роста степени воцерковленности. Так, доля прихожан, прислушивавшихся к мнению единоверцевобщинников, увеличивается с 8,3\% в группе маловоцерковленных до 21,2\% в группе сильновоцерковленных; процент прихожан, полностью перекладывающих свой электоральный выбор на плечи общинников, не превышает $2 \%$ и появляется только среди воцерковленных и сильновоцерковленных. Вместе с тем соотношение верующих, которые не руководствовались мнением общинников при принятии решения о том, за кого голосовать, во всех группах оказывается приблизительно одинаковым и колеблется около отметки $70 \%$, т.е. прирост доли прислушивающихся прихожан обеспечивается за счет группы респондентов, затруднившихся с ответом. Данная группа по мере увеличения воцерковленности уменьшается с $25 \%$ в группе маловоцерковленных до 6,8\% среди сильновоцерковленных (рисунок 8). Зафиксированное распределение подтверждает гипотезу $\mathbf{H}_{3}$ : «чем чаще человек посещает службы, тем чаще он прислушивается к мнению общинников по политическим вопросам».

\section{Руководствовались ли Вы мнением членов религиозной общины, в которой Вы состоите, при принятии решения о голосовании за ту или иную партию/кандидата?}

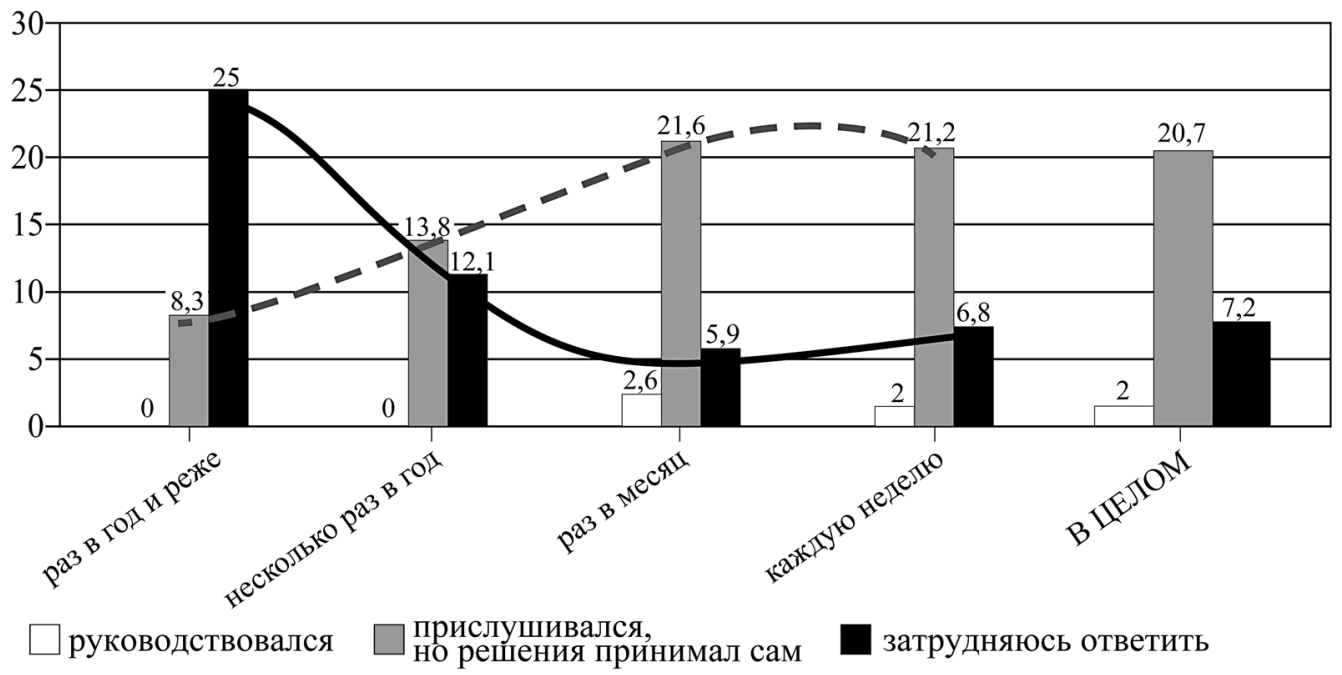

Рисунок 8. Соотношение воцерковленности и доли прихожан, которые при голосовании полагаются на мнения состоящих с ними в одной общине единоверцев ${ }^{13}, \%$

13 Участие в приходской жизни неминуемо сопрягается с посещением храмов и религиозных служб, поэтому в результате проведения кросс-табуляции группа невоцерковленных православных (верующих, которые не посещают службы) оказалась не наполненной. 
Согласно вышеизложенному, 22,7\% православных верующих, в той иной мере принимающих участие в жизни церковной общины, при принятии решения о голосовании полагаются на мнение общинников. Однако активно участвующие в жизни общины прихожане подпадают под влияние не только общинников, но и священников. Кроме общения с товарищами по общине, они также могут быть очевидцами массовой агитации, проводимой духовенством, могут и самостоятельно спрашивать у священнослужителей совета. Так, среди прихожан, прислушивающихся к мнению общинников, 65,6\% при голосовании полагается еще и на мнение священника ${ }^{14}$. Разграничение перекрываемых подмножеств позволяет выделить долю прихожан, которые не были очевидцами политической агитации клиpa, не спрашивали совета у священников и при голосовании полагались только на мнения общинников. Среди православных, принимающих участие в жизни общины, данная группа занимает $21,7 \%$, а в выборке в целом их доля составляет 6,6\%.

\section{Заключение}

В представленной работе была затронута проблема соотношения политического и религиозного в современном российском обществе. В исследовании была предпринята попытка прояснить, оказывают ли представители православного духовенства и общинники воздействие на электоральный выбор верующих. Роль священников в процессе формирования электоральных предпочтений верующих была рассмотрена на примере осуществляемой духовенством прямой и косвенной политической агитации. Авторами исследования был проведен социологический опрос, на материалах которого проверялись гипотезы о распространенности, направленности и эффективности агитационного воздействия клира и общинников.

В ходе исследования было выявлено, что 18,4\% православных верующих, попавших в выборку, были свидетелями того, как священнослужитель во время проповеди высказывался по вопросам политического характера. При этом увеличению частоты посещения религиозных служб сопутствует возрастание доли верующих, ставших очевидцами проводимой духовенством политической агитации (среди наиболее воцерковленной группы православных доля очевидцев составляет более четверти). Таким образом, можно говорить о наличии системного воздействия клира на электоральные предпочтения верующих.

Было зафиксировано, что 14,5\% попавших в выборку православных при принятии решения о том, за кого голосовать, в той или иной степени полагаются на мнение священника, при этом примерно половина из них получала рекомендации во время проповеди $(7,4 \%)$, а половина $(7,1 \%)$ самостоятельно обратилась за советом. Причем доля полагающихся на мнение священника возрастает по мере увеличения степени воцерковленности православных верующих, достигая 22,6\%.

Вместе с тем в ходе исследования было обнаружено, что 6,6\% попавших в выборочную совокупность православных верующих не были свидетелями ни массо-

\footnotetext{
14 Свидетелями массовой политической агитации со стороны священника в этой группе стали лишь 35,8\%, т.е. среди прихожан, полагающихся на мнения общинников, почти треть $(29,8 \%)$ респондентов, не будучи очевидцами массовой агитации священника, самостоятельно обратились к нему с соответствующими вопросами.
} 
вой, ни индивидуальной агитации, проводимой священником, однако при формировании своих электоральных предпочтений полагались на мнение общинников.

На основании полученных результатов можно заключить, что в современной России религия оказывает ощутимое воздействие на электоральные предпочтения верующих. Как минимум 21,1\% православных верующих, попавших в выборку, при принятии решения о своем электоральном выборе находятся под непосредственным влиянием священников и общинников.

Подводя итог, необходимо отметить, что результаты данного исследования позволяют утвердительно ответить на поставленный в названии работы вопрос: в современной России православные священники и общинники оказывают воздействие на электоральные предпочтения верующих, причем воздействие может быть инициировано как священниками, так и самими верующими.

\section{Литература}

В КПРФ не поняли статью 14 Основного закона. Конституционному суду предложат найти четкоеопределение для светского государства(2017)//Независимая газета. 25 мая 2017// http://www.ng.ru/politics/2017-05-25/1 6995 kprf.html

Выбор все-таки за нами (2011) // Православие.ru. 24 ноября 2011 // http://www.pravoslavie.ru/50052.html

«Единая Россия» и РПЦ договорились сотрудничать (2010) // Коммерсантъ. 16 июля 2010 // https://www.kommersant.ru/doc/1442587

Епископ Евтихий агитирует за Путина (2012) // YouTube.com // http://www.youtube.com/watch?v=0772sCgCzOM

Зоркая Н.А. (2013) Православие в постсоветском обществе // Общественные науки и современность. № 1. С. 89-106.

Зюганов считает Христа «первым коммунистом в новом летоисчислении» (2016) // TACС 20 апреля $2016 / /$ http://tass.ru/obschestvo/3223717

Зюганов: кодекс строителя коммунизма и нагорная проповедь полностью совпадают (2012)// Новые Известия. 15 апреля 2012 // http://www.newizv.ru/lenta/2012-04-15/162277zjuganov-kodeks-stroitelja-kommunizma-i-nagornaja-propoved-polnostju-sovpadajut.html

Идти и голосовать? (2011) // Православие и мир. 2 декабря 2011 // https://www.pravmir.ru/idti-i-golosovat/

Коммунизм и православие (2016) // КПРФ // http://www.zyuganov.kprf.ru/news/ pravoslavie-i-kommunizm

Кулькова А.Ю. (1) (2015) Взаимосвязь религиозности и социального консерватизма: Россия и Европа // Общественные науки и современность. № 3. С. 141-154.

Кулькова А.Ю. (2) (2015) Религиозность и политическое участие: роль политики в российских религиозных общинах. Препринт WP14/2015/02. М.: ВШЭ.

Локосов В.В. (2006) Влияет ли религиозность на политическую консолидацию общества? // Социологические исследования. № 11. С. 82-89.

Локосов В.В., Синелина Ю.Ю. (2004) Религиозная ситуация в Ярославской области. М.: РИЦ ИСПИ РАН.

Локосов В.В., Синелина Ю.Ю. (2008) Взаимосвязь религиозных и политических ориентаций православных россиян // Мчедлов М.П. (ред.) Религия в самосознании народа (Религиозный фактор в идентификационных процессах). М.: Институт социологии РАН. C. 106-125.

На политические взгляды $35 \%$ опрошенных влияет священник (2016) // Грузия Online. 29 июля 2016 // https://www.apsny.ge/2016/soc/1469848121.php

Общественное мнение-2012 (2012). М.: Левада-Центр. 
Основы социальной концепции РПЦ (2000) // РПЦ ОВЦС // https://mospat.ru/ru/documents/social-concepts/

Особое мнение с В. Жириновским (2016) // Эхо Москвы. 14 сентября 2016 // http:/echo.msk.ru/programs/personalno/1837620-echo/

Открытое письмо православных верующих по поводу участия Церкви в предвыборной агитации (2011) // ИАЦ Сова. 15 ноября 2011 // https://www.sova-center.ru/religion/news/authorities/elections/2011/11/d23022/

Патриарх Кирилл призвал верующих участвовать в президентских выборах (2017) // РИА Новости. 26 декабря 2017 // https://ria.ru/20171226/1511735983.html

Практика заявлений и действий иерархов, духовенства, монашествующих и мирян во время предвыборных кампаний. Проблема выдвижения духовенством своих кандидатур на выборах (2011) // Официальный сайт Московского Патриархата. 2 февраля 2011 // http://www.patriarchia.ru/db/text/1400896.html

Представители религиозных организаций и политологи о религиозном факторе в предвыборной борьбе (2003) // ИАЦ Сова. 16 июля 2003 // https://www.sova-center.ru/religion/discussions/authorities/2003/07/d664/

Протоиерей Владимир Головин отвечает на вопросы паломников в Свято-Авраамиевском храме города Болгара (2018) // YouTube.com // https://www.youtube.com/watch?v=Tc3u4m51MrM

Руководство «Единой России» решило напоследок помолиться на Афоне (2018) // Znak. com. 16 октября 2016 // https://www.znak.com/2018-10-16/rukovodstvo_edinoy_ rossii_reshilo_naposledok_pomolitsya_na_afone

«Русская православная церковь не участвует в предвыборной агитации, но призывает россиян идти на выборы», митрополит Иларион (2018) // Интерфакс. Религия. 13 марта $2018 / / \mathrm{http}: /$ www.interfax-religion.ru/?act=news\&div=69427

Рябых Ю.А. (2004) Политические партии России и Русская Православная Церковь // Полития. № 1. С. 124-148.

Священник Александр Шумский: «С оптимизмом смотрю на нашу будущую политическую жизнь» (2011) // Православие и мир. 2 декабря 2011 // https://www.pravmir.ru/ svyashhennik-aleksandr-shumskij-ya-s-optimizmom-smotryu-na-nashu-budushhuyupoliticheskuyu-zhizn/

Сергей Миронов посетил Храм Покрова Пресвятой Богородицы в Уссурийске (2011) // Официальный сайт С.М. Миронова. 13 ноября 2011 // http://mironov.ru/news/ sergej-mironov-posetil-hram-pokrova-presvyatoj-bogoroditsy-v-ussurijske/

Ситников А.В. (2012) Православие, институты власти и гражданского общества в России. СПб.: Алетейя.

Соборное согласие: почему КПРФ и РПЦ больше не враги (2016) // ВВС. 27 апреля 2016 // https://www.bbc.com/russian/society/2016/04/160427_tr_kprf_orthodox_church_symbiosis

Социальные сети в России, весна $20 \overline{15}$. Цифры, тренды, прогнозы (2015) // Brand Analytics. 6 июня 2015 // http://br-analytics.ru/blog/socialnye-seti-v-rossii-vesna-2015-cifry-trendy-prognozy

Ткачев А. (2017) Библейские требования к власти // Православие.ru. 15 ноября 2017 // http://www.pravoslavie.ru/108095.html

Федеральный закон «Об основных гарантиях избирательных прав и права на участие в референдуме граждан Российской Федерации» от 12.06.2002 №67-Ф3 // http://www.consultant.ru/document/cons_doc_LAW_37119/

«Церковь будет соблюдать нейтралитет на выборах», - -заявил Патриарх Алексий II (2003) // Newsru.com. 7 декабря 2017 // http://www.newsru.com/religy/25apr2003/interview.html

«Церковь - над предвыборной “схваткой”». Диалог при свете «лампады». Читателям «Труда» отвечает митрополит Смоленский и Калининградский Кирилл (2003) // РПЦ ОВЦС. 3 ноября 2003 // https://mospat.ru/archive/2003/11/nr311033/

Церковь не будет поддерживать «Единую Россию» на выборах в Госдуму, хотя Патриарх назвал их важными (2011) // Газета.ru. 25 апреля $2011 / /$ http://www.gazeta.ru/news/lenta/2011/05/25/n_1854601.shtml

Чаплин напомнил священникам о недопустимости политической агитации (2011) // Интерфакс. 22 ноября 2011 // http://www.interfax.ru/russia/217837 
Чеснокова В.Ф. (2005) Тесным путем: Процесс воцерковления населения России в конце XX века. М.: Академический проект.

Calfano B.R., Oldmixon E.A. (2015) Primed Parsons: Reference Groups and Clergy Political Attitudes // Journal of Religion \& Society, vol. 17, pp. 1-10.

Knutsen O. (2004) Religious Denomination and Party Choice in Western Europe: A Comparative Longitudinal Study from Eight Countries, 1970-97 // International Political Science Review/ Revue Internationale de Science Politique, vol. 25, no 1, pp. 97-128.

Many Americans Hear Politics from the Pulpit (2016) // Pew Research Center, August 8, 2016 // http://www.pewforum.org/2016/08/08/many-americans-hear-politics-from-the-pulpit/

McTague J.M., Layman G.C. (2009) Religion, Parties, and Voting Behavior // The Oxford Handbook of Religion and American Politics, New York: Oxford, pp. 330-370.

Van der Brug W., Hobolt S.B., de Vreese C.H. (2009) Religion and Party Choice in Europe // West European Politics, vol. 32, no 6, pp. 1266-1283.

Wald K.D., Calhoun-Brown A. (2014) Religion and Politics in the United States, Rowman \& Littlefield.

Wald K.D., Owen D.E., Hill S.S. (1988) Churches as Political Communities // American Political Science Review, vol. 82, no 2, pp. 531-548.

\title{
Politics in the Church: Do Priests Influence the Electoral Preferences of Orthodox Believers?
}

\author{
M. BOGACHEV*, K. SORVIN**
}

\begin{abstract}
*Maksim Bogachev - PhD in Sociology, Lecturer, National Research University Higher School of Economics. Address: 20, Myasnitskaya St., Moscow, 101000, Russian Federation. E-mail: mbogachev@hse.ru

**Kirill Sorvin - PhD in Philosophy, Associate Professor, Deputy Dean of the Faculty of Social Sciences, National Research University Higher School of Economics. Address: 3, Krivokolennyj Lane, Moscow, 101000, Russian Federation. E-mail: ksorvin@hse.ru

Citation: Bogachev M., Sorvin K. (2019) Politics in the Church: Do Priests Influence the Electoral Preferences of Orthodox Believers? Mir Rossii, vol. 28, no 4, pp. 68-91 (in Russian). DOI: 10.17323/1811-038X-2019-28-4-68-91
\end{abstract}

\begin{abstract}
This paper clarifies whether representatives of the Orthodox clergy impact the electoral choices of believers, focusing on the case of agitation by the clergy. Empirically the study draws on a sociological survey conducted 2014-2015 via the social network "Vkontakte" among people identifying themselves as Orthodox believers $(\mathrm{N}=2,735)$. The study reveals that $18.4 \%$ of respondents witnessed Orthodox priests speak about political issues during religious services. $14.5 \%$ of respondents reported relying on the opinions of priests in making electoral decisions, and the intensity of church attendance was positively correlated with the incidence of such accounts. $6.6 \%$ of respondents did
\end{abstract}


not report any political recommendations by priests, but in their electoral preferences they nevertheless relied on the opinion of Orthodox community members. The results allow us to conclude that religion has a non-trivial effect on the electoral preferences of believers in modern Russia. At least $21.1 \%$ of respondents could be identified as being exposed to the direct political influence of priests and Orthodox community members.

Key words: the sociology of religion, the political science of religion, politics and religion, election, Orthodoxy, campaign (agitation), "United Russia"

\section{References}

Calfano B.R., Oldmixon E.A. (2015) Primed Parsons: Reference Groups and Clergy Political Attitudes. Journal of Religion \& Society, vol. 17, pp. 1-10.

Chaplin napomnil svyashchennikam o nedopustimosti politicheskoj agitatsii [Chaplin Reminded the Priests about the Inadmissibility of Political Agitation] (2011). Interfax, November 22, 2011. Available at: http://www.interfax.ru/russia/217837, accessed 31.08.2019.

Chesnokova V.A. (2005) Tesnym putem: Protsess votserkovleniya naseleniya Rossii v kontse $X X$ veka [Close Way: the Process of Churching the Population of Russia in the Late XX century], Moscow: Academic project.

«Edinaya Rossiya» i RPC dogovorilis' sotrudnichat' [United Russia and the Russian Orthodox Church Agree to Cooperate] (2010). Kommersant, July 16, 2010. Available at: https://www.kommersant.ru/doc/1442587, accessed 31.08.2019.

Episkop Evtihij agitiruet za Putina [Bishop Eutykhiy Agitates for Putin] (2012). Youtube.com. Available at: http://www.youtube.com/watch? $\mathrm{v}=0772 \mathrm{sCgCzOM}$, accessed 31.08.2019.

Federal'nyj zakon "Ob osnovnykh garantiyakh izbiratel'nykh prav i prava na uchastie $v$ referendume grazhdan Rossijskoj Federatsii» ot 12.06.2002 №67-FZ [Federal Law "On Basic Guarantees of Electoral Rights and the Right to Participate in the Referendum of Citizens of the Russian Federation" of 12.06.2002 No. 67-FZ]. Available at: http://www.consultant.ru/document/cons_doc_LAW_37119/, accessed 31.08.2019.

Idti i golosovat'? [Go and Vote?] (2011). Pravmir.ru, December 2, 2011. Available at: https://www.pravmir.ru/idti-i-golosovat/, accessed 31.08.2019.

Knutsen O. (2004) Religious Denomination and Party Choice in Western Europe: A Comparative Longitudinal Study from Eight Countries, 1970-97. International Political Science Review/ Revue Internationale de Science Politique, vol. 25, no 1, pp. 97-128.

Kommunizm i pravoslavie [Communism and Orthodoxy] (2016). KPRF site. Available at: http://www.zyuganov.kprf.ru/news/pravoslavie-i-kommunizm, accessed 31.08.2019.

Kul'kova A.Yu. (1) (2015) Vzaimosvyaz' religioznosti i sotsial'nogo konservatizma: Rossiya i Evropa [The Relationship between Religiosity and Social Conservatism: Russia and Europe]. Social Sciences and Contemporary World, no 3, pp. 141-154.

Kul'kova A.Yu. (2) (2015) Religioznost' i politicheskoe uchastie: rol' politiki v rossijskikh religioznykh obshchinakh [Religiousness and Political Participation: the Role of Politics in Russian Religious Communities]. Preprint WP14/2015/02, Moscow: HSE.

Lokosov V.V. (2006) Vliyaet li religioznost' na politicheskuyu konsolidatsiyu obshchestva? [Does Religiosity Affect Political Consolidation?]. Sociological Studies, no 11, pp. 82-89.

Lokosov V.V., Sinelina Yu.Yu. (2004) Religioznaya situatsiya $v$ Yaroslavskoj oblasti [Religious Situation in the Yaroslavl Region], Moscow: RIC ISPI RAN.

Lokosov V.V., Sinelina Yu.Yu. (2008) Vzaimosvyaz' religioznykh i politicheskikh orientatsij pravoslavnykh rossiyan [Interrelation of Religious and Political Orientations of Orthodox Russians]. Religiya $v$ samosoznanii naroda (Religioznyj faktor $v$ identifikacionnykh 
protsessakh) [Religion in the Self-Consciousness of People (Religious Factor in Identification Processes)] (ed. Mchedlov M.P.), Moscow: Institut sociologii RAN, pp. 106-125.

Many Americans Hear Politics from the Pulpit (2016). Pew Research Center, August 8, 2016. Available at: http://www.pewforum.org/2016/08/08/many-americans-hear-politicsfrom-the-pulpit/, accessed 31.08.2019.

McTague J.M., Layman G.C. (2009) Religion, Parties, and Voting Behavior. The Oxford Handbook of Religion and American Politics, New York: Oxford, pp. 330-370.

$\mathrm{Na}$ politicheskie vzglyady $35 \%$ oproshennykh vliyaet svyashchennik [The Political Views of $35 \%$ of Respondents are Influenced by Priests] (2016). Georgia Online, July 29, 2016. Available at: https://www.apsny.ge/2016/soc/1469848121.php, accessed 31.08.2019.

Obshchestvennoe mnenie-2012 [Public Opinion-2012] (2012), Moscow: Levada-Centre.

Osnovy sotsial'noj kontseptsii RPC [The Foundations of the Social Concept of the Russian Orthodox Church] (2000). The Russian Orthodox Church. Department for External Church Relations. Available at: https://mospat.ru/ru/documents/social-concepts/, accessed 31.08.2019.

Osoboe mnenie s V. Zhirinovskim [Special Opinion with V. Zhirinovsky] (2016). Radio Echo Moscow, September 14, 2016. Available at: http://echo.msk.ru/programs/personalno/1837620-echo/, accessed 31.08.2019.

Otkrytoe pis'mo pravoslavnykh veruyushchikh po povodu uchastiya Tserkvi v predvybornoj agitatsii [An Open Letter to Orthodox Believers about the Participation of the Church in Election Campaigning] (2011). Sova-center, November 15, 2011. Available at: https://www. sova-center.ru/religion/news/authorities/elections/2011/11/d23022/, accessed 31.08.2019.

Patriarh Kirill prizval veruyushchikh uchastvovat' v prezidentskikh vyborakh [Patriarch Kirill Urges Believers to Participate in the Presidential Election] (2017). RIA Novosti, December 26, 2017. Available at: https://ria.ru/20171226/1511735983.html, accessed 31.08.2019.

Praktika zayavlenij i dejstvij ierarkhov, dukhovenstva, monashestvuyushchikh i miryan vo vremya predvybornykh kampanij. Problema vydvizheniya dukhovenstvom svoikh kandidatur na vyborakh [The Practice of Statements and the Actions of Hierarchs, Clergy, Monastics and Laity during Election Campaigns. The Problem of Nomination by the Clergy of Their Candidacies in the Elections] (2011). The Russian Orthodox Church, February 2, 2011. Available at: http://www.patriarchia.ru/db/text/1400896.html, accessed 31.08.2019.

Predstaviteli religioznykh organizatsij i politologi o religioznom faktore $\mathrm{v}$ predvybornoj bor'be [Representatives of Religious Organizations and Political Scientists about the Religious Factor in the Election Campaign] (2003). Sova-center, July 16, 2003. Available at: https:/www.sova-center.ru/religion/discussions/authorities/2003/07/d664/, accessed 31.08.2019.

Protoierej Vladimir Golovin otvechaet na voprosy palomnikov v Svyato-Avraamievskom khrame goroda Bolgara [Archpriest Vladimir Golovin Answers the Questions of Pilgrims in the Holy Avraamievsky Temple of the city of Bolgar] (2018). YouTube.com. Available at: https://www.youtube.com/watch?v=Tc3u4m51MrM, accessed 31.08.2019.

Rukovodstvo «Edinoj Rossii» reshilo naposledok pomolit'sya na Afone [The Leadership of United Russia Finally Decides to Pray on Athos] (2018). Znak.com, October 16, 2018. Available at: https://www.znak.com/2018-10-16/rukovodstvo edinoy rossii reshilo naposledok pomolitsya na afone, accessed 31.08.2019.

«Russkaya pravoslavnaya tserkov' ne uchastvuet $\mathrm{v}$ predvybornoj agitatsii, no prizyvaet rossiyan idti na vybory», mitropolit Ilarion ["The Russian Orthodox Church Does Not Participate in Election Campaigning, but Urges Russians to Participate in the Polls", Metropolitan Hilarion] (2018). Interfax, March 13, 2018. Available at: http://www.interfax-religion.ru/?act=news\&div=69427, accessed 31.08.2019.

Ryabykh Yu.A. (2004) Politicheskie partii Rossii i Russkaya Pravoslavnaya Tserkov' [Political Parties of Russia and the Russian Orthodox Church]. Politeia, no 1, pp. 124-148.

Sergej Mironov posetil Khram Pokrova Presvyatoj Bogoroditsy v Ussurijske [Sergey Mironov Visits the Church of the Intercession of the Holy Virgin in Ussuriysk] (2011). S. Mirornov's personal site, November 13, 2011. Available at: http://mironov.ru/news/sergej-mironovposetil-hram-pokrova-presvyatoj-bogoroditsy-v-ussurijske/, accessed 31.08.2019.

Sitnikov A.V. (2012) Pravoslavie, instituty vlasti $i$ grazhdanskogo obshchestva $v$ Rossii [Orthodoxy, Institutions of Power and Civil Society in Russia], Saint Petersburg: Aletejya. 
Sobornoe soglasie: pochemu KPRF i RPC bol'she ne vragi [Conciliar Consent: Why the Communist Party of the Russian Federation and the Russian Orthodox Church Are no Longer Enemies] (2016). BBC, April 4, 2016. Available at: https://www.bbc.com/russian/society/2016/04/160427_tr_kprf_orthodox_church_symbiosis, accessed 31.08.2019.

Sotsial'nye seti v Rossii, vesna 2015. Tsifry, trendy, prognozy [Social Networks in Russia, Spring 2015. Figures, Trends, Forecasts] (2015). Brand Analytics, June 6, 2015. Available at: http://br-analytics.ru/blog/socialnye-seti-v-rossii-vesna-2015-cifry-trendy-prognozy, accessed 31.08.2019.

Svyashchennik Aleksandr Shumskij: «S optimizmom smotryu na nashu budushchuyu politicheskuyu zhizn'» [Priest Alexander Shumsky: "I Look with Optimism at Our Future Political Life"] (2011). Pravmir.ru, December 2, 2011. Available at: https:/www.pravmir.ru/svyashhennik-aleksandr-shumskij-ya-s-optimizmom-smotryuna-nashu-budushhuyu-politicheskuyu-zhizn/, accessed 31.08.2019.

Tkachov A. (2017) Biblejskie trebovaniya k vlasti [Biblical Requirements for Power]. Pravoslavie.ru, November 15, 2017. Available at: http://www.pravoslavie.ru/108095.html, accessed 31.08.2019.

«Tserkov' - nad predvybornoj "skhvatkoj"». Dialog pri svete «lampady». Chitatelyam «Truda» otvechaet Mitropolit Smolenskij i Kaliningradskij Kirill ["The Church over pre-Election "Struggle". Dialogue in the Light of the "Lamp". Metropolitan Kirill of Smolensk and Kaliningrad Responds to Readers of "Trud"] (2003). The Russian Orthodox Church. Department for External Church Relations, November 3, 2003. Available at: https://mospat.ru/archive/2003/11/nr311033, accessed 31.08.2019.

«Tserkov' budet soblyudat' nejtralitet na vyborakh», - zayavil Patriarh Aleksij II ["The Church Will Comply with Election Neutrality”, Declared Patriarch Alexy II] (2003). Newsru.com, December 7, 2017. Available at: http://www.newsru.com/religy/25apr2003/interview.html, accessed 31.08.2019.

Tserkov' ne budet podderzhivat' «Edinuyu Rossiyu» na vyborah v Gosdumu, khotya Patriarh nazval ikh vazhnymi [The Church Will Not Support "United Russia" in the Elections to the State Duma, although the Patriarch Called Them Important] (2011). Gazeta.ru, April 25, 2011.Available at: http://www.gazeta.ru/news/lenta/2011/05/25/n_1854601.shtml, accessed 31.08.2019.

V KPRF ne ponyali stat'yu 14 Osnovnogo zakona. Konstitutsionnomu sudu predlozhat najti chetkoe opredelenie dlya svetskogo gosudarstva [The Communist Party Does Experiencing Problems with Understanding Article 14 of the Basic Law. Constitutional Court Will Be Offered to Find a Clear Definition for a Secular State] (2017). Nezavisimaya gazeta, May 25, 2017. Available at: http://www.ng.ru/politics/2017-05-25/1_6995_kprf.html, accessed 31.08.2019.

Van der Brug W., Hobolt S.B., de Vreese C.H. (2009) Religion and Party Choice in Europe. West European Politics, vol. 32, no 6, pp. 1266-1283.

Vybor vse-taki za nami [The Choice is still Ours] (2011). Pravoslavie.ru, November 24, 2011. Available at: http://www.pravoslavie.ru/50052.html, accessed 31.08.2019.

Zorkaya N.A. (2013) Pravoslavie v postsovetskom obshchestve [Orthodoxy in the post-Soviet Society]. Social Sciences and Contemporary World, no 1, pp. 89-106.

Zyuganov schitaet Khrista «pervym kommunistom v novom letoischislenii» [Zyuganov Considers Christ "the First Communist in the Nominal Calendar"] (2016). TASS, April 20, 2016. Available at: http://tass.ru/obschestvo/3223717, accessed 31.08.2019.

Zyuganov: kodeks stroitelya kommunizma i nagornaya propoved' polnost'yu sovpadayut [Zyuganov: the Code of the Builder of Communism and the Sermon on the Mount Completely Coincide] (2012). Novye Izvestiya, April 15, 2012. Available at: http://www.newizv.ru/lenta/2012-04-15/162277-zjuganov-kodeks-stroitelja-kommunizmai-nagornaja-propoved-polnostju-sovpadajut.html, accessed 31.08.2019.

Wald K.D., Calhoun-Brown A. (2014) Religion and Politics in the United States, Rowman \& Littlefield.

Wald K.D., Owen D.E., Hill S.S. (1988) Churches as Political Communities. American Political Science Review, vol. 82, no 2, pp. 531-548. 